\title{
ON THE FOUNDATION OF MATHEMATICA SCANDINAVICA
}

\author{
BODIL BRANNER
}

\section{Introduction}

In 1953 two new Scandinavian journals appeared, Mathematica Scandinavica and Nordisk Matematisk Tidskrift, since 1979 also named Normat. Negotiations among Scandinavian mathematicians started with a wish to create an international research journal accepting papers in the principal languages English, French and German, and expanded quickly into negotiations on another more elementary journal accepting papers in Danish, Norwegian, Swedish, and occasionally in English or German. The mathematical societies in the Nordic countries Denmark, Finland, Iceland, Norway and Sweden were behind both journals and for the elementary journal also societies of schoolteachers in Denmark, Finland, Norway and Sweden.

The main character behind the creation of the two journals was the Danish mathematician Svend Bundgaard. The negotiations were essentially carried out during 1951 and 1952. Although the title of this paper signals that this is the story behind the creation of Math. Scand., it is also - although to a lesser extent - the story behind the creation of Nordisk Matematisk Tidskrift. The stories are so interwoven in time and in persons involved that it would be wrong to tell one without the other. Many of the mathematicians who are mentioned in the following are famous for their mathematical achievements, this text will however only focus on their role in the creation of the journals and the different societies involved.

The sources used in this paper are found in the archives of Math. Scand., mainly letters, minutes of meetings, and drafts of documents. Some supplementary letters from the archives of the Danish Mathematical Society have proved useful as well. The archives are located at the mathematics departments at the University of Aarhus respectively the University of Copenhagen. The creation of the journals is well documented.

Received May 20, 2003. 


\section{Early negotiations on a high level Scandinavian journal - the year 1950 and before}

Discussions started in the summer of 1950 between the Danish mathematician Børge Jessen and the Swedish mathematician Arne Beurling. Jessen's idea was to replace the small Danish journal Matematisk Tidsskrift, series $B$ by a new international journal where Scandinavian mathematicians were likely to publish their original research papers and reach the international mathematical community. Matematisk Tidsskrift had been published (under slightly varying names) since 1859. In 1890 it was split into an elementary series A and a high level series B, and since 1919 the Danish Mathematical Society - Dansk Matematisk Forening - had been in charge of its publication. The papers were published in Danish, although papers in the series B were also accepted in English, French and German. Jessen served as editor of Matematisk Tidsskrift B for many years and had often expressed a wish to replace the journal by a more international one.

The time was ripe for new international initiatives and revival of former international activities. The first International Congress of Mathematicians (ICM) after the Second World War took place at Harvard University in the USA in 1950 (30 August to 6 September). It was preceded by a conference in New York in order to re-establish the International Mathematical Union (IMU) which had stopped working in the thirties. The delegates at this conference represented twenty-two countries, including Denmark, Finland, Norway and Sweden. Jessen used this opportunity to talk with Beurling and the Norwegian mathematician Thoralf Skolem about the possibility of an international Scandinavian journal. An Interim Executive Committee of the IMU was set up with Jessen as the secretary and six other members, but no president. In September 1951 Jessen could declare the official founding of the IMU.

It is worth noticing that Jessen, Beurling and Skolem were members of the editorial board of the prestigious international journal Acta Mathematica. This journal had been published in Sweden since December 1882 with Gösta Mittag-Leffler as its first chief editor. Acta has always been truly international and has at the same time always had an editorial board consisting exclusively of Scandinavian mathematicians. In 1950 its chief editor was the Danish mathematician and geodecian Niels Erik Norlund. He was a member of the editorial board from 1921 to his death in 1981.

The Swedish Mathematical Society - Svenska Matematikersamfundet - is the youngest of the Scandinavian mathematical societies. The inaugural meeting of the society took place in June 1950. Beurling became its first president, and at a meeting in the society in November that year he presented the idea of a new international mathematical journal to be published by the Scandinavian mathematical societies jointly. The new society was highly interested in an 
organ for its activities. If for some reason a new Scandinavian journal with the Swedish Mathematical Society as co-publisher would not materialize, other possibilities were either to start a new Swedish journal or to enlarge the existing Swedish journal Arkiv för Matematik.

At the same time Jessen presented the idea to the Executive Committee of the Danish Mathematical Society. The committee had three members: Harald Bohr as president, Fr. Fabricius-Bjerre as substitute for its secretary Werner Fenchel who was in the USA at the time, and Bundgaard as treasurer. The society formed a committee to discuss the idea further. The committee consisted of the three Danish members of the editorial board of Acta Mathematica: Jessen, Jakob Nielsen, Nørlund, and as representatives of the Mathematical Society: Bundgaard and Fabricius-Bjerre. Bohr had participated in the early negotiations, but died in January 1951. Fabricius-Bjerre acted as president after Bohr's death and was elected president in the spring of 1951.

Jessen stopped being editor of Matematisk Tidsskrift B in 1950 due to his other obligations. Bundgaard and Fenchel were elected as co-editors; they edited the last two volumes of the journal that appeared in 1951 and 1952; all papers were in English, French or German, except the one Bohr submitted in Danish just before he died.

On the initiative of Fabricius-Bjerre and Bundgaard the statutes of the Mathematical Society was changed in 1952. One of the consequences was an extension of the Executive Committee to five people. Jessen became a member of the enlarged body and was to succeed Fabricius-Bjerre as president of the society from 1954 to 1958 . Fenchel became president from 1958 to 1962.

Fabricius-Bjerre and Bundgaard saw great potentials in a closer collaboration among the Nordic mathematical societies, in particular in connection with the creation of joint publications. They were convinced that the scientific level among university mathematicians and the level of schoolteachers in mathematics would in general improve in all the Nordic countries due to such initiatives. With great energy and enthusiasm they worked closely together in the following couple of years to reach the goal.

\section{Negotiations on both a high level and an elementary Scandinavian journal - in the first half of $\mathbf{1 9 5 1}$}

Already in February 1951 Bundgaard drafted a letter to the other Scandinavian mathematical societies with a plan for a high level Scandinavian journal. In this letter he proposed a very optimistic time schedule, namely before 1st of May to make the mathematical societies agree to the plan, and to appoint a person to form a committee to finalize this. He hoped the plan could be approved by 1st of July by all the societies, so that the first issue of the journal could be prepared in the fall of 1951 and appear in 1952. The drafts were discussed 
with Fabricius-Bjerre; moreover an estimate of the cost of printing had been obtained from a printer. Discussions should continue in the Danish committee, and an application for funding should be sent as soon as possible. FabriciusBjerre and Bundgaard felt well prepared when they met in early March with the other members of the Danish committee. Jessen, Jakob Nielsen and Nørlund had received copies of the different drafts in advance.

A private letter from Bundgaard to Fenchel gives a lively description of what happened at the meeting. (The letter has an inserted note telling that it was never mailed.) Nørlund torpedoed the plans. After many years of economical independence Acta Mathematica was facing in recent years a dramatic rise in the price for printing, so much that he would have to apply for funding in Denmark and Sweden and most likely in competition with a possible new journal. Furthermore, Nørlund was chairman of Rask- Ørsted Fondet, the most obvious foundation to support both Acta and a new Scandinavian journal. This was an understandable worry and a possible conflict. However, Nørlund also - what they had never dreamed of - feared scientific competition. Jessen of course argued warmly for the cause, but no arguments made an impression. Jakob Nielsen gave less than half-hearted support. The 'older' colleagues were less excited than the 'younger' ones. During the next year it became clear that a large majority of the editors of Acta was in favour of the high level journal, but still Rask-Ørsted Fondet was not asked for financial support to the new journal.

Clearly, Fabricius-Bjerre and Bundgaard were not to give up. They were hoping that the Swedes would have a strong and united position in favour of the high level journal. Bundgaard discussed this with Nils Erik Fremberg, treasurer in the Swedish Mathematical Society, in Lund in March, and he invited him to participate in the memorial ceremony for Bohr in Copenhagen on the 6th of April. On this occasion Fremberg could then - confidentially if necessary - inform them about the further negotiations in the Swedish Mathematical Society.

At the same time Bundgaard and Fabricius-Bjerre started to work for an elementary Scandinavian journal as well, in the beginning they concentrated on a Danish-Norwegian collaboration. The Norwegian Mathematical Society - Norsk Matematisk Forening - had been founded in November 1918, and published from 1919 the journal Norsk Matematisk Tidskrift. This journal published papers in Norwegian, mainly of an elementary nature. The Danish elementary series A of Matematisk Tidsskrift could not continue alone if series B was replaced by a high level Scandinavian journal. Both the Danish and the Norwegian journal were used as exchange objects. In 1951 the Danish Matematisk Tidsskrift was sent to a large number of libraries and departments of mathematics all over the world, and in exchange the library at 
the Department of Mathematics at University of Copenhagen received about 135 other mathematical journals. The department paid half price for the copies sent abroad in exchange.

By end of April, Bundgaard was invited to visit Bergen University. He applied for and obtained a grant from the Foundation for Danish-Norwegian Collaboration - Fondet for Dansk-Norsk Samarbejde - to spend the month of May at Lysebu close to Oslo, owned by the foundation, and given as a gift from Norway to Denmark in 1945. His main reason for the extended stay was a wish to examine the possibilities of a closer collaboration among the mathematical societies in Norway and Denmark, in particular concerning joint publication activities.

Bundgaard informed the Norwegian mathematicians, in particular Viggo Brun, president of the Norwegian Mathematical Society, about the plan to start a high level Scandinavian journal published by the Scandinavian mathematical societies jointly. He admitted that the idea was not fully supported by Danish mathematicians, and described the possible economical difficulties, and the relation to Acta Mathematica. He was convinced that a new journal could not bother Acta, on the contrary it could complement Acta, so that Acta could keep its high standing or even improve it further. The Norwegian mathematicians supported this viewpoint, and they were eager to have a discussion in principle among the Scandinavian mathematical societies as soon as possible. They were also willing to enter into substantial negotiations. Note that Brun, too, was an editor of Acta.

The Norwegians were ready to enter into a collaboration between the Danish series A of Matematisk Tidsskrift and Norsk Matematisk Tidskrift, but in the beginning more cautious to support an elementary Scandinavian journal. It would not be easy for them to give up the Norwegian journal that several of them had struggled for some 30 years earlier. However, during the month-long visit of Bundgaard, there was a growing sympathy towards this idea and a wish to discuss it among mathematicians in the different Scandinavian countries, including high school teachers. If such a Scandinavian journal should be a reality the Norwegians would appreciate that it - at least in the beginning would be published in Norway, and that it would be used in exchange for other journals. They did not wish to start an elementary Danish-Norwegian journal without having asked the Swedes and the Finns if they would like to join.

In the beginning of June, the annual meeting of the Swedish Mathematical Society took place in Lund. Scheduled was also a meeting among the national committees concerning the Scandinavian congresses in mathematics. Bundgaard and Fabricius-Bjerre wanted to have a discussion of publication activities as well. However, prior to the meeting Fabricius-Bjerre wrote to Bundgaard that it was unfortunate (and likely to complicate negotiations) that 
the Danes were divided in the question about the high level journal. His viewpoint was that, concerning series B, they could not take any initiative, but would have to remain passive and let the initiative come from outside; an unpleasant and weak position. Concerning series A, they were in a free and good position to discuss. Fabricius-Bjerre recommended moving slowly and letting the affairs mature gradually. In the end it was most likely that there would be two joint Scandinavian journals, since it was such a reasonable and sensible idea.

Luckily, the Swedes improvised a meeting about the journals. Present were from Sweden: Beurling, Åke Pleijel, Fremberg, Marcel Riesz, G. Hössjer; from Norway: Skolem; from Denmark: Bundgaard, Fabricius-Bjerre, Jessen, Jakob Nielsen. The Swedes supported strongly a high level Scandinavian journal. They were - because of consideration for the Swedish journal Elementa and in particular its editor Carl Emanuel Blom - not yet ready to join an elementary journal. Minutes from the meeting were written by Beurling and Pleijel and were later sent to all the Scandinavian mathematical societies. The societies were asked to appoint contact persons who were to meet in Stockholm in the fall for further negotiations in connection with the next meeting in the Swedish Mathematical Society. Basic principles for the journal were discussed during the Lund meeting, and a long list of suggestions were agreed upon. Among those: that the title of the journal should be in Latin; that each of the Scandinavian mathematical societies should appoint a member of the editorial board and in addition agree on a co-ordinating editor/chief editor - redaktionssekretcer; that Denmark should have priority in using the journal in exchange for other journals, but that Finland should be second. The reason behind was that Sweden used Acta Mathematica in exchange, and that Norway should obtain priority in exchange for the planned elementary journal. Costs of printing production should be estimated in the different countries before the Stockholm meeting. The first issue was scheduled to be published in the beginning of 1953 .

Pleijel played an important role in the creation of both journals. He succeeded Beurling as president of the Swedish Mathematical Society from 1952 to 1957, and became the first Swedish editor of Math. Scand. Fremberg played an important role in supporting the Swedish participation in the elementary journal, he was appointed editor by the Swedish Mathematical Society of this journal, but he died unfortunately of cancer in September 1952 before the journal had started. Riesz was member of the editorial board of Acta Mathematica.

The Danes who had been present at the meeting in Lund continued to worry about the relation to Acta. They wanted to have added to the draft of the minutes that it had been mentioned that the new journal in no way may 
cause a weakening of the position of Acta as a first rank international journal. Beurling refused to include this remark with the argument, that certainly the new journal had never been thought to offend the interests of Acta.

\section{Full speed forward in the negotiations for both journals - the second half of 1951}

The Swedish initiative and support was sufficient for Fabricius-Bjerre and Bundgaard to move on. Fabricius-Bjerre first wrote to Brun about the meeting in Lund. Brun immediately responded. He supported Fabricius-Bjerre's idea to contact the Finns as soon as possible. In the same letter Brun suggested to simply name a new elementary journal as Nordisk Matematisk Tidskrift (i.e. to exchange Norwegian with Nordic) in analogy with the wish to use Nordic or Scandinavian in some Latin form in the name of the high level journal.

In the beginning of July, Fabricius-Bjerre wrote to Pekka Juhana Myrberg, president of the Finnish Mathematical Society - Suomen Matemaattinen Yhdisty, to inform him about the plans. He announced that Myrberg would later receive an official letter from Beurling. As starting point Fabricius-Bjerre used the meeting in Lund, there was no reason any more to refer back to the earlier private negotiations among the Danes as he explained to Bundgaard. Of particular concern was the elementary journal. In August a Scandinavian congress for schoolteachers in mathematics was to take place in Finland. The president of the Danish Society of Teachers in Mathematics at high schools and teachers' colleges - Foreningen af matematiklarere ved gymnasieskoler og seminarier $i$ Danmark - would be present as well as the editor Regnar Norgil of series A of Matematisk Tidsskrift, so discussions about the elementary journal could be continued and extended during this meeting. Myrberg answered in early August that the Finns would collaborate in the further negotiations on both journals. Myrberg had discussed the plans for an elementary journal with E. Johannes Nyström. Although there were already two journals in Finland with similar aims their understanding was that both university mathematicians and schoolteachers in mathematics would welcome such a joint journal. The two Finnish journals were: Arkhimedes, published jointly by the Finnish Mathematical Society and the Finnish Physical Society with Myrberg as chief editor, and another journal published in Finnish by the Finnish Society of Teachers in Mathematics and Physics - Suomen matematiikan ja fysiikan opettajien liitto. Note that Myrberg, too, was an editor of Acta. He was also chief editor of the international journal Annales Academice Scientiarum Fennica that he had founded in 1941. Nyström was to become editor of the elementary journal, appointed by the Finnish Mathematical Society.

In August, Fabricius-Bjerre suggested in a letter to Brun that the Norwegians should organize a meeting in Oslo concerning the elementary journal, to follow 
up on the planned meeting in Stockholm during the fall concerning the high level journal. Brun agreed. Prior to the meetings, he again expressed worries about the creation of an elementary journal and foresaw the possibility of status quo for Norsk Matematisk Tidskrift. The further development would especially depend on the views of the Swedish mathematicians.

The meeting in Stockholm took place on the 6th of November and continued on the 8th. Present were the contact persons appointed by the mathematical societies, from Denmark: Bundgaard, Fabricius-Bjerre, from Norway: Brun, Skolem, from Sweden: Beurling, Pleijel and as secretary Fremberg. There was no representative from Finland. A contract between the Scandinavian mathematical societies was drafted. The editors were to be appointed for periods of four years, starting from January 1953, although it was hoped that the initial editorial board should begin to function in April 1952. The journal should have one volume consisting of two issues per year, corresponding to about twenty papers. The economy of the journal was to be guaranteed through annual contributions from the mathematical societies in the proportions: three ninth from the Swedish society and two ninth from the Danish, Finnish and Norwegian each. The division was based on the number of inhabitants in the different countries. Members of the societies should be able to subscribe to the journal at half of the ordinary subscription rate. It was discussed to form a group of experts to assist the editors in judging the submitted papers. The idea of a well-defined group of experts was given up later. Moreover, it was noted that the journal should contain research papers, mainly of limited size and mainly of work carried out in the Scandinavian countries. Messages from the different societies could be published. The proposals of production cost from the different countries were compared. It was noted that the Danish one was the most advantageous, and it was decided to publish the journal in Copenhagen for the time being. Different titles of the journal in Latin were discussed. It was decided that Bundgaard, Fremberg and Pleijel should be responsible for finalizing the contract so that it could be signed. Note that in this small group both Swedes had a favourable attitude towards an elementary Scandinavian journal.

The mathematical meeting of the Swedish society took place on the 7th of November with nine mathematical talks of which four were given by: Bundgaard, Brun, Fabricius-Bjerre, and Skolem.

On the 8th of November the elementary journal was discussed shortly. However, the main discussions took place in Norway on the 12th and 13th of November, partly at Lysebu. From Norway participated: Brun, Ingebrigt Johansson, Kay Piene, Skolem, Ralph Tambs Lyche, Knut Thalberg; from Denmark: Bundgaard, Fabricius-Bjerre. Since the high level journal was now decided upon, research papers which had previously been submitted to Norsk 
Matematisk Tidskrift were in the future to be submitted to the high level journal. In any case it would not be possible to continue Norsk Matematisk Tidskrift and series A of Matematisk Tidsskrift in Denmark exactly as before. Among the Norwegians Tambs Lyche and Piene were the strongest advocates of a joint Scandinavian elementary journal. Thalberg who was responsible for the mathematics library in Oslo worried about the possible collapse of the exchange agreements with Norsk Matematisk Tidskrift. If the journal was kept as a local elementary journal without research papers it would have little interest outside Norway. There was some disagreement among the three who had participated in the meeting in Stockholm in their interpretation of Swedish support to an elementary journal. In Brun's opinion, Beurling in particular, had only little interest in and little understanding of the importance of such a journal. In Fabricius-Bjerre's and Bundgaard's opinion Beurling was more supportive, and they reminded the Norwegians of the support from Finland. In any case, the Danes convinced the Norwegians that the possibility of an elementary Scandinavian journal should not be abandoned before detailed plans had been worked out and negotiations had been carried to an end with all potential partners.

It was decided to let Brun, Bundgaard and Johansson work out details, and to leave the further initiative to the Danish Mathematical Society. Bundgaard, essentially based on the experiences from the high level journal, worked out a plan.

The two Norwegian editors of the elementary journal were to become Tambs Lyche, representing the Norwegian Mathematical Society, and Piene, representing the teachers. Since 1930 Skolem had been one of the editors of the Norwegian journal, and since 1946 Piene had been the other. Johansson had been president of the Norwegian Mathematical Society from 1946 to 1951, and Tambs Lyche was to succeed Brun as such from 1960 to 1966. Johansson became the first co-ordinating editor/chief editor - redaktionssekretcer of Nordisk Matematisk Tidskrift. However, already during the first year of the journal he was succeeded as such by Ernest S. Selmer who carried on until 1979 and therefore was the person who really came to shape the journal.

Fabricius-Bjerre had been authorized to inform the Icelandic mathematicians that the other Scandinavian mathematical societies would welcome a member of the Icelandic society as a joint editor of the high level journal. In November he wrote a letter to Ólafur Dan Danielsson in Reykjavík to inform him about the journal and that the economical support from the society was expected to be proportional to the number of inhabitants in each country, hence it was set to $1 \%$ for Iceland. The Icelandic Mathematical Society - Íslenzka stcerðfraðafélagið - had been founded in October 1947 on Danielsson's 70th birthday. Danielsson immediately gave a positive response. 
Myrberg sent the Finnish comments to the draft of the contract for the high level journal. The comments were prepared by himself and Rolf Nevanlinna, the two Finnish editors of Acta.

No doubt, the most important next step for Fabricius-Bjerre and Bundgaard was to obtain the support of the elementary journal by the Swedes. At the end of November, Bundgaard wrote to Fremberg about both the high level and the elementary journal. Different titles in Latin for the high level journal were discussed. But the letter was mainly to keep Fremberg informed about the further Danish-Norwegian plans for the elementary journal. The plan could be used in Sweden as well, to inform those who might be interested as long as it was stressed that this was for the time being a Danish-Norwegian working document. Bundgaard signalled that he would be happy if Fremberg could find an opportunity to inform Beurling and win him for the project. Think of the international traditions: mathematicians like Felix Klein in Germany, Borel, Hadamard, Lebesgue and Tannery in France; journals like L'Enseignement Mathématique in France, Elemente der Matematik in Switzerland, Mathematical Monthly in the USA, etc. Bundgaard made a plan for getting in touch with Swedish teachers in mathematics. He wanted to obtain an invitation to a meeting in the Society of Mathematics and Natural Science Education in Stockholm - Föreningen för matematisk-naturvetenskaplig undervisning i Stockholm where he could present the idea of the elementary journal. Perhaps, Fremberg could also contact the editor of Elementa and talk with him about the plans; Elementa did not have to fear a drop in number of subscriptions, the content in physics and chemistry was sufficient to make a continuation of subscription obvious in all of Scandinavia. Even before the meeting in Stockholm, Bundgaard participated in the beginning of December in a meeting in Lund of the corresponding society, the Society of Mathematics and Natural Science Education in Lund. Through his acquaintance with Fremberg he was allowed to inform shortly about the plans of the elementary journal. Some time after the meeting he obtained full support for the elementary journal from the society in Lund.

\section{The plans for both journals finalized - in the year 1952 and early 1953}

In early January 1952 Bundgaard travelled to Stockholm to participate in the teachers meeting. He had himself become aware of the meeting and wanted to participate. In the meantime the Danish Society of Mathematics Teachers had received an invitation to send a representative. They nominated Bundgaard as their representative. At the end of December 1951 Bundgaard informed by letters several Swedish persons, in particular Bror Gustaver, secretary of the Swedish society in Stockholm, about the plans for the elementary journal and 
asked him to arrange a small meeting in Stockholm, prior to the big meeting, for those particularly interested in discussing the plans. He also informed Fremberg and Pleijel about his visit to Stockholm and his wish to have them participate in the smaller meeting. Fabricius-Bjerre wrote to Beurling and explained that the Danish Mathematical Society would appreciate if Bundgaard could visit Beurling in Uppsala and give a first-hand briefing of the development in the plans of both the high level and the elementary journal. Bundgaard also wrote to Bo Kjellberg, secretary of the Swedish Mathematical Society, and asked him to arrange a small meeting in Uppsala, similar to the one in Stockholm, in connection with his visit there. Bundgaard was immediately after his arrival to Stockholm asked to come to Uppsala. He was met at Uppsala station by Kjellberg. He was practically dismissive of a joint elementary journal and had not arranged the small meeting Bundgaard had hoped for. Kjellberg argued that the Swedes had Elementa and would not be very interested; moreover, Beurling was of the same opinion as him. Bundgaard was not put off, after all he had convinced the Norwegians, so it should be possible to convince the Swedes as well. He gave a detailed description of the latest issues of Norsk Matematisk Tidskrift and Matematisk Tidsskrift, series A, emphasizing the papers that would have been suited for the new elementary journal. Further, he stressed that in Denmark and Norway there was a tradition for university mathematicians to be interested in school mathematics, this seemed to be less prominent in Sweden. A Scandinavian collaboration would lift the level among schoolteachers in mathematics. These were arguments Bundgaard was to use again and again. It turned out that Beurling was a lot more supportive than Kjellberg had expressed. He emphasized that the young Swedish Mathematical Society could not take a lead in the creation of an elementary journal and could not take economically responsibility for this. But in fact he was willing to let the society support an elementary journal if the societies of schoolteachers and those involved in Elementa would give their support as well.

In the further negotiations Bundgaard was in a strong position, he could speak as the official representative of four societies, the mathematical societies and the mathematical teachers' societies of both Denmark and Norway. In Stockholm Gustaver had arranged a small pre-meeting. Present were among others Stig Comet who was related to Elementa, Karl Persson, later better known under the name Dragerholm, he was to be appointed editor by the teachers' society in Stockholm, and Pleijel. Blom, the editor of Elementa, had been invited too, but did not participate in order not to limit the discussion. Comet reported that Blom supported the initiative, he did not fear the competition. Bundgaard spoke at the big meeting and several more discussions took place during the next days. In the end of Bundgaard's stay there seemed to be a predominant positive support to the proposal among the Swedish teachers. 
Bundgaard also paid a visit to Blom. He described him as a strong character who was extremely well informed about academic questions and the situation at universities and schools in Scandinavia. Blom had rescued Elementa in 1931 in a critical moment. From 1931 to 1961 he almost single-handedly edited Elementa, published it and distributed it as well. No wonder that so many people had great admiration for him and were careful not to interfere with his life's work. However, Blom supported a joint Scandinavian elementary journal in mathematics. He only feared that the Swedish contributions would be rather few and that the university mathematicians would not show sufficient interest. He could also foresee a complicated editorial structure with so many editors from different countries involved.

At the Stockholm meeting Bundgaard also met B. L. Stara who had just become a member of the board of the Finnish Society of Teachers in Mathematics and Physics. His personal opinion was that there would be a great interest among Finnish schoolteachers in mathematics for the elementary journal. He reported that Myrberg had not contacted the schoolteachers and complained about the lack of collaboration between university mathematicians and schoolteachers in Finland. He offered to be an intermediary between the Danish negotiators and the Finnish schoolteachers; an offer which should prove to be most valuable.

In total, Bundgaard's travel to Sweden had been extremely successful. He immediately reported back to Brun and Piene about the further development.

In January 1952, all the Scandinavian mathematical societies were asked to discuss (possibly with the help of philologists) the following four proposed titles of the high level journal

Mathematica Scandinavica

Forum Mathematicum Scandinaviae

Analecta Scandinavica Mathematica

Symbolae Scandinavicae Mathematicae

and to send back a prioritized list. The majority was in favour of Mathematica Scandinavica.

In February 1952, Fabricius-Bjerre mailed the final draft of the contract to the different mathematical societies with the title of the journal included. If all the societies could approve the contract it was to be printed and sent around in five copies for signing, and Math. Scand. would be a reality. The first editorial meeting would be arranged in Denmark. During February and March the contract was agreed upon with minor changes at general assemblies by the different societies, moreover editors were appointed. From Denmark: Fenchel, from Finland: Gustav Elfving, from Iceland: Leifur Ásgeirsson, from Norway: Skolem, and from Sweden: Pleijel. Immediately after the decisions 
had been taken Fenchel, in agreement with Pleijel, wrote to the other editors and suggested Bundgaard as co-ordinating editor of Math. Scand. The first editorial meeting was held 22nd and 24th May at Schaefergården in Copenhagen, the Danish counterpart to Lysebu, both owned by the Foundation for DanishNorwegian Collaboration. All editors except Ásgeirsson were present. In 1954 Bundgaard was appointed full professor at the University of Aarhus where he founded the Department of Mathematics. The editorial office of Math. Scand. moved to Aarhus with him and it has remained there since. He continued as coordinating editor until 1971 when he was elected chancellor of the University. The volume 27 from 1970 became the last to contain society notes.

It took another year to finalize the negotiations on Nordisk Matematisk Tidskrift. But in the end all Scandinavian mathematical societies backed the journal and so did the relevant Scandinavian societies of teachers, all together ten societies. In May 1952, Bundgaard sent around the first draft of a contract. Most of the editors had been chosen by then under the condition that the journal would be a reality; from Denmark David Fog by the Danish Mathematical Society and Norgil by the Danish Society of Teachers in Mathematics; from Finland Nyström by the Finnish Mathematical Society; from Norway Tambs Lyche by the Norwegian Mathematical Society, and Piene by the section of teachers in mathematics in the Norwegian Society of Teachers - Norsk Lektorlags matematikkseksjon; from Sweden Fremberg by the Swedish Mathematical Society and Persson (Dagerholm) by the Swedish Society for Mathematics and Natural Science Education in Stockholm. A meeting was arranged at Schæffergaarden 2nd June. Present were all editors except Tambs Lyche, and also Bundgaard. Thereafter a revised contract was sent to the relevant societies for further discussion. The formal approval came for most societies in the fall of 1952, but informally the support was there and the work could begin.

In March Fabricius-Bjerre had informed the Icelandic Mathematical Society about the plans. The society decided to join and appointed in June Sigurkarl Stefánsson as editor. In early July the first financial support to both journals was received in Copenhagen. It came from the Ministry of Education in Iceland and was received with great appreciation. Twice during 1953 Math. Scand. received a substantial grant from the Life Insurance Companies of Iceland. Other grants to meet expenses connected with the inauguration of the journals came in 1953 from Statens Almindelige Videnskabsfond in Denmark for Math. Scand., and from Clara Lachmanns Fond in Sweden for Nordisk Matematisk Tidskrift.

The first editorial meeting of Nordisk Matematisk Tidskrift was held 16th and 18th August in Oslo. Present were the editors who had been appointed so far, including Johansson as co-ordinating editor, with the exception of Fremberg who was ill, and Stefánsson. Bundgaard was also present. Strongly sup- 
ported by Fabricius-Bjerre who had told Bundgaard that he would feel a lot safer if he was present, Bundgaard had requested to be allowed to participate in the last preparatory meeting and was invited to do so. The draft of the contract was again discussed, and it was decided to declare the journal a reality as soon as six out of the possible ten societies had officially joined. If six were reached before 1st of December 1952 the journal was to start in 1953; by the end of November eight societies had officially joined. Denmark and Norway were ready to share the economical responsibility in 1953 and 1954, but hereafter all countries should be equally responsible. It turned out to be difficult to have the journal printed in Norway. So, it was printed in Copenhagen until 1979 by the same printer as Math. Scand. The two new Scandinavian journals were to have a close collaboration. In many years to come, Bundgaard received copies of letters sent to the editorial board of Nordisk Matematisk Tidskrift. After the first editorial meeting two new Swedish editors were appointed. The Swedish Mathematical Society had originally chosen Fremberg as editor and had agreed that Fremberg, being in Lund, could also represent the Swedish Society for Mathematics and Natural Science Education in Lund. After his death in September 1952 the Swedish Mathematical Society appointed Hans Rådström as editor and the society in Lund appointed Carl-Erik Fröberg.

The last society to join was the Finnish Society of Teachers in Mathematics and Physics. Already at the end of February 1952, Bundgaard had participated in the annual meeting of this society in Helsinki to inform the Finnish schoolteachers about the plans. Bundgaard had wanted to use the same strategy as in Sweden. However, the president of the society Urpo Kuuskoski was very negative. He did not wish to initiate a meeting in a smaller group prior to the big meeting, hence Bundgaard invited specially interested teachers to his hotel. Although there was a strong support among the teachers in mathematics it proved difficult to receive any official responses from the Finnish society of teachers, and it became clear afterwards that Kuuskoski internally worked against Finnish participation. Stara kept Bundgaard informed. He wrote that in principle the Finns would join, they had decided who should be responsible for further negotiations and also discussed as possible editor Inkeri Simola, the first female doctor in mathematics in Finland, then a schoolteacher. However, no official letters reached Copenhagen prior to the editorial meeting in August, although several reminders were sent. Stara and Nyström became more and more frustrated, in fact Nyström suggested confidentially to Bundgaard to send an ultimatum to Kuuskoski. The Finnish Mathematical Society was ready to appoint Simola as a second editor in any case. Only a mild ultimatum was formulated since it was necessary to wait for the formal approval of the Swedish society of teachers in Stockholm, this came in February 1953. And, finally, in February 1953 the Finnish society of teachers officially agreed to 
join and appointed Simola as editor. The editorial board was now complete, but the editorial work had been going on for quite some time.

The contract for Nordisk Matematisk Tidskrift was circulated in February and March 1953 and signed by all ten societies.

The two journals were a reality. Bundgaard had succeeded in his tour de force.

ACKNOWLEDGEMENT. I am grateful to the editors of the journal for having asked me to write this paper and for letting me have free access to the archives of Math. Scand. It has been personally awarding for me to follow the close collaboration between Bundgaard and Fabricius-Bjerre. In different ways they have shaped my mathematical life: Bundgaard while I was a student at University of Aarhus in the sixties and later on Fabricius-Bjerre when I was employed at the Technical University of Denmark as amanuensis (assistant professor) directly under his professorship. I also wish to thank those who have given valuable information and comments to an earlier version of this paper, in particular Bent Birkeland, Torkil Heiede, Jesper Lützen, Ulf Persson, Martin Raussen, Jón Ragnar Stefánsson.

DEPARTMENT OF MATHEMATICS

TECHNICAL UNIVERSITY OF DENMARK

2800 KGS. LYNGBY

DENMARK 